\title{
Scrap superannuation
}

It fails to meet the standards of a retirement income system. It is costly and inefficient, unnecessary, and incredibly unfair.

The age pension system is by far the most economically efficient retirement income system.

Scrap superannuation. Expand the age pension. Boost the economy.

Dr Cameron K. Murray

January 2020

http://fresheconomicthinking.com

Cameron is an economist, author, and consultant. His areas of expertise include public policy, property and urban development, environmental economics, and corruption. 


\section{Executive Summary}

Economically, there can be only one retirement income system. This system allocates goods and services at the time they are needed to retirees who do not have alternative non-work income sources to sustain a socially acceptable level of welfare.

Superannuation does not fulfil the requirements of a retirement income system. Instead, it is best thought of as a growth-sapping, resource-wasting, tax-advantaged asset purchase scheme for the wealthy, which may ultimately have little effect on reducing reliance on the age pension system.

The age pension vastly outperforms superannuation as a retirement income system across three key areas.

\section{Microeconomic cost}

- The superannuation system employs 55,000 people at a cost of $\$ 36$ billion per year, to provide $\$ 40$ billion in benefits. This is nearly as many people as the enlisted Australian Defence Force $(58,000)$ with a similar total cost ( $\$ 34$ billion).

- Australia's complete welfare system, including administering the age pension, disability, unemployment benefits, and Medicare, costs just $\$ 6$ billion per year and employs 33,000 people while providing $\$ 45$ billion in pension benefits.

\section{Macroeconomic efficiency}

- Each year the superannuation system redirects $\$ 38$ billion of wages from the real economy into asset markets, sapping demand and growth. Each year this is roughly the size the $\$ 40$ billion stimulus package of 2009 implemented following the financial crisis, but is instead a reduction, rather than a boost, to demand.

- The age pension system is likely to be stimulatory because it transfers purchasing power from high-income taxpayers with a low marginal propensity to consume to lower-income pensioners with a high marginal propensity to consume.

\section{Fairness}

- Unlike the age pension system, the superannuation system cannot provide poverty relief, nor ensure broad coverage and adequacy of retirement incomes.

- The superannuation system does not smooth lifetime consumption for the bottom $40 \%$ of income earners. Instead, it makes them poorer when they are poor and working, and richer when they are rich and retired.

- The $\$ 45$ billion per year in tax breaks to the rich in the superannuation system also means it fails to meet redistributive standards.

Vested interests perpetuate economic myths to avoid scrutiny of the superannuation system, such as 1) that the age pension system is financially constrained, 2) that prefunding via asset purchases increases the capacity of a retirement income system, and 3 ) that superannuation is a payment from employers rather than from wages.

Scrapping the superannuation system would massively improve Australia's economic performance, and thus the performance of our retirement income system, the age pension. This can be done by forcing employers to pay what is now superannuation directly into wage accounts and allowing all super fund holders to withdraw up to a maximum amount each year during a transition period, after which all super balances will receive no special tax treatment. The age pension system could also be enhanced in both size (payment rates, including rent assistance) and scope (reducing the age that people qualify from 67 to 60 ), vastly increasing the fairness and efficiency of Australia's retirement income system and economy as a whole. 


\section{Table of Contents}

Executive Summary

How to think about retirement as a public policy issue 3

The microeconomic cost perspective 3

The macroeconomic efficiency perspective 3

$\begin{array}{ll}\text { The fairness perspective } & 3\end{array}$

$\begin{array}{ll}\text { What is superannuation? } & 4\end{array}$

What is the age pension? $\quad 4$

Economic equivalence (or lack thereof) 5

$\begin{array}{ll}\text { Microeconomic cost assessment } & 5\end{array}$

$\begin{array}{ll}\text { Macroeconomic efficiency assessment } & 7\end{array}$

$\begin{array}{ll}\text { Fairness assessment } & 8\end{array}$

Coverage, poverty relief, and adequacy $\quad 8$

$\begin{array}{ll}\text { Consumption smoothing } & 9\end{array}$

$\begin{array}{ll}\text { Generational equity and redistribution } & 10\end{array}$

$\begin{array}{ll}\text { Myths that sustain the system } & 10\end{array}$

How to boost wages, growth, well-being, and retirement 12

$\begin{array}{ll}\text { Scrap superannuation } & 12\end{array}$

$\begin{array}{ll}\text { Enhance the only retirement income system we have } & 13\end{array}$

$\begin{array}{ll}\text { Turn the retirement income system into a citizen income? } & 13\end{array}$

Scrap Superannuation $\quad 2$ 


\section{How to think about retirement as a public policy issue}

When it comes to retirement income systems "there can be only one". That immortal system allocates goods and services society produces at the time they are needed to retirees who do not have the alternative non-work income sources necessary to sustain a socially acceptable level of welfare.

That's it. No economic theory disputes it. All retirement income systems must be a type of social insurance that performs this same resource allocation function. Alternative ways to achieve this can be evaluated from three economic perspectives.

\section{The microeconomic cost perspective}

The micro-economic question about retirement income policy is, therefore, how to allocate resources to income-poor retirees most efficiently. Which system uses the fewest labour and capital resources in the allocation process?

\section{The macroeconomic efficiency perspective}

The macro-economic question concerns the effect of the retirement resource allocation system on growth, demand, and incentives for investment that expands the productive capacity of the economy as a whole. Does the system stimulate investment and economic activity, or depress it?

\section{The fairness perspective}

Lastly, a retirement income system can be judged on its fairness. Does it allocate resources sufficiently to those in need while allocating from those with relatively high resource access (i.e. high incomes and/or wealth)?

The Organization for Economic Cooperation and Development (OECD) has a set of principles regarding the performance of retirement income systems that broadly fall into these three categories. ${ }^{1}$

This report assesses Australia's public age pension and compulsory private savings (superannuation) systems across these three areas. The main finding is that superannuation fails on all accounts - it uses a vast amount of resources, it reduces investment incentives, and is entirely unfair, worsening inequality. In fact, given that it fails the three criteria for a retirement income system, it could be argued that it is not, in fact, a retirement income system at all.

Indeed, Australia's economic performance would be vastly enhanced if superannuation was scrapped. Scrapping superannuation involves 1) removing the tax advantages to saving, 2) removing the compulsion to contribute to superannuation, and 3) allowing people to spend their super balances. We, therefore, conclude the report by outlining the expected economic benefits of scrapping the superannuation system.

\footnotetext{
${ }^{1}$ Though they ignore the microeconomic perspective. Their macroeconomic principle is to ensure labour force participation with incentives to participate in the workforce. Their fairness principles are broad, including poverty relief, pension benefit adequacy, coverage, which together account for a minimum level of access to resources in retirement. Consumption smoothing is a fairness principle that ensures the system takes resources from an individual when they are richer and gives back when they are poorer. Lastly, they include inter-and intra-generational equity and redistribution, which concerns whether the system takes resources from richer individuals and gives to poorer ones both within and between generations.

They also include a "financial sustainability" criteria. This is unfortunate, as only constraint on retirement incomes are real resources-money can always be created to fund the system. Real resource constraints cannot be overcome with different accounting arrangements.

OECD. (2018). Pensions Outlook. http://www.oecd.org/daf/fin/private-pensions/OECD-Pensions-Outlook-2018Highlights.pdf
} 


\section{What is superannuation?}

Superannuation is a tax-advantaged way to purchase financial assets using wages or other income sources. Rather than being taxed as an income flow, superannuation allows up to $\$ 25,000$ per year of wages to be redirected to asset purchases without being subject to income tax. It is compulsory for $9.5 \%$ of wages, minimum, to be used on these superannuation asset purchases.

At age 56 (incrementing up to age 60), people with superannuation accounts are able to withdraw funds to finance their lifestyle, though they must wait until age 60 to withdraw all their funds tax-free.

From a system perspective, the allocation of resources to retirees occurs on net from the trade of previously accumulated assets (both capital values and asset incomes) to non-retirees, as shown in Figure 1 below.
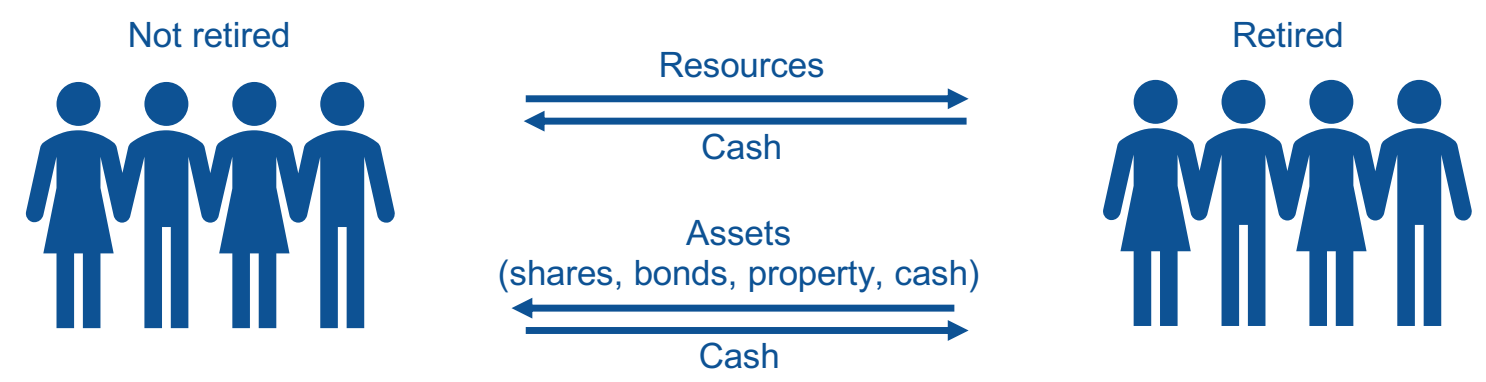

Figure 1: Net resource allocations in the superannuation system

\section{What is the age pension?}

The age pension is a fortnightly cash payment made to individuals over the qualifying age, currently 66 but incrementing up to 67 by 2023. For single retirees older than pension age they get $\$ 933$ per fortnight (tax-free due to age carve-outs in the tax system) and for couples, they get $\$ 1,407$. Renter retirees can get an additional payment of around $\$ 130$ per fortnight.

Age pension payments are made by the Australian Treasury, and hence from a system perspective are funded by some combination of taxation, bond issuance, and seigniorage ${ }^{2}$, depending on fiscal settings. On net, these funding arrangements transfer purchasing power to the retirees receiving the age pension, as shown in Figure 2.
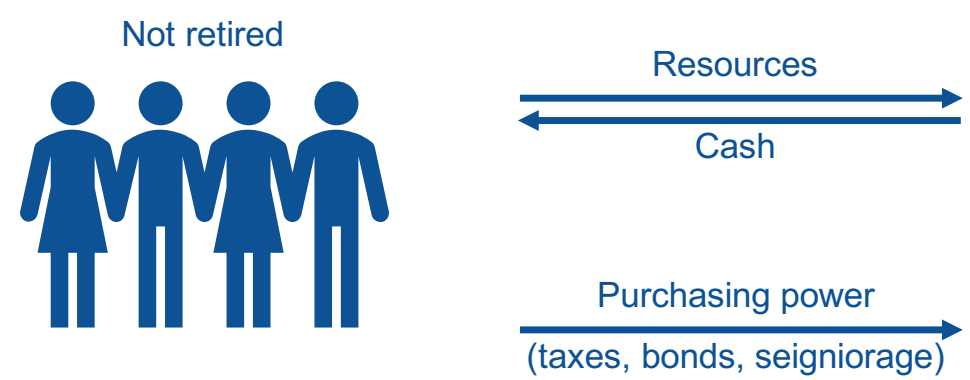

Retired

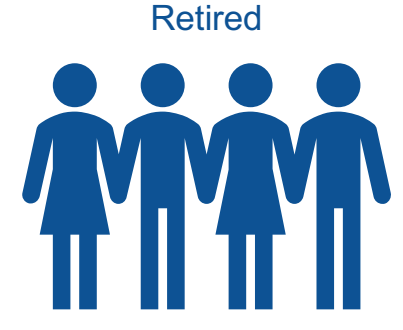

Figure 2: Net resource allocations in the age pension system

\footnotetext{
${ }^{2}$ Seigniorage is a tax in the form of inflation from the creation of additional money.
} 


\section{Economic equivalence (or lack thereof)}

Because there is only one retirement income system, these two approaches must be equivalent, economically speaking. This means that the idea that superannuation can "take pressure off the age pension system" is actually a statement of ideological preference, not economic viability. If ageing, for example, is perceived as a problem for the age pension, it is equally a problem for all alternative retirement systems, including superannuation. After all, there is only one retirement system. If the superannuation system can, for example, allocate $\$ 60$ billion per year of resources to retirees, then the age pension system can also allocate $\$ 60$ billion per year of resources, as can any other retirement system. ${ }^{3}$ The only difference is that purchasing power is given to retires with asset sales in one scenario and with various public funding alternatives, including taxes, in the other. There is no magic pudding arising from simply using a different accounting method in the superannuation system compared to the age pension.

However, these systems are not equivalent for a different reason. Thus, one of these systems is not a retirement income system.

Unlike the age pension, superannuation does not allocate resources to retirees who do not have the alternative non-work income sources necessary to sustain a socially acceptable level of welfare.

Because superannuation relies on previous personal incomes, it does not allocate resources to retirees without alternative prior work income sources. While in principle the system aims to create alternative income sources from broadening asset ownership amongst retirees, this does not make it a retirement income system. Retirees who have little or no superannuation, or have spent their superannuation, still require resources to be allocated to them. The superannuation system cannot serve an insurance function.

A better description of superannuation is a tax-advantaged asset purchase system for high income-earners. Its effect on the way resources are allocated to retirees is almost incidental. This reality is reflected in numerous finer details of the superannuation system. For example, the age criteria to spend from superannuation is much lower than the age pension. Superannuants can withdraw their money eight years earlier than the age pension, in their mid-50s. Indeed, at age 60, superannuants can remove all their superannuation balance and spend it on consumption goods immediately. Details like these (and others ${ }^{4}$ ) show that superannuation is not a retirement income system.

\section{Microeconomic cost assessment}

Which system uses the fewest labour and capital resources in the allocation process? We can answer this question by looking at the labour force involved in each system, and the management cost of each system as a proxy for the total economic resources consumed. We can compare this resource cost to the amount of income each system allocates to retirees and the number of retirees receiving an income.

Australia's superannuation industry employs around 55,000 people and cost $\$ 34$ billion in fees in $2018 .{ }^{5}$ As a reference, this is nearly the same workforce as the Australian

\footnotetext{
${ }^{3}$ One such system is the Retiree Token described in Murray, C. (2020). The easiest retirement system—Retiree Tokens. Fresh Economic Thinking. https://www.fresheconomicthinking.com/2020/01/the-easiest-retirement-system-retiree.html

${ }^{4}$ See Denniss, R. and D. Richardson. (2012). Can the taxpayer afford 'self-funded retirement'? Policy Brief No. 42. The Australia Institute. https://www.tai.org.au/sites/default/files/PB\%2042\%20Can\%20the\%20taxpayer\%20afford\%20selffunded\%20retirement 4.pdf

${ }^{5}$ The sum of the workforce in the ANZSIC 633 (Superannuation Funds) and 6419d (Superannuation Funds Management Services) classifications from

Ibisworld. (2019). Superannuation funds in Australia-Market research report.

https://www.ibisworld.com.au/industry-trends/market-research-reports/financial-insurance-services/superannuation-
} 
Defence Force's (ADF) 58,000 strong permanent force ${ }^{6}$ The cost of Australia's military is also similar, at $\$ 34$ billion per year. But this total cost also accounts for reservists and the 19,000 public servants supporting the ADF. For perspective, people spend twice as much each year managing their super than they do on electricity. ${ }^{7}$

The superannuation system currently provides retirement incomes of $\$ 40.1$ billion per year (in 2019). ${ }^{8}$ The system provided an additional $\$ 39.9$ billion of lumpsum withdrawals. These may or may not go to retirees, and their very existences suggests that superannuation is mostly a tax-advantaged asset purchase scheme. In total, 1.4 million people were provided an income from the system.

The size of the labour force necessary to run Australia's age pension system can be determined by looking at the total staffing of the Department of Human Services (DHS), which runs all national welfare programs, including Medicare and Centrelink. In 2018 the DHS employed 33,000 people. ${ }^{9}$ Even if up to a fifth of these staff were involved in administering the age pension system, that would be only 7,000 people.

The administration costs of the age pension are some fraction of the DHS total budget of around $\$ 5$ billion. Taking the one-fifth assumption as before, that means the age pension system costs about $\$ 1$ billion per year to run. Meanwhile, it allocates about $\$ 45$ billion of retirement income to 2.5 million pensioners.

Table 1 summarises the key resource efficiency statistics of each system. While the performance of the superannuation system will improve over time as a larger share of account holders retire, the system as a whole is unlikely to ever be anywhere near as micro-economically efficient as the age pension system, which delivers retirement incomes at $4 \%$ of the cost of the superannuation system and $12 \%$ of the workforce.

Table 1: Microeconomic costs of superannuation and the age pension ( ${ }^{+}$plus $39.9 \mathrm{~b}$ lumpsum)

\begin{tabular}{l|cc} 
& Superannuation & Age pension \\
\hline Total Workforce & 55,000 & $<7,000$ \\
Total Costs $\mathbf{( \$ b / y r ) ~}$ & 36 & $<1.7$ \\
Income to retirees $\mathbf{( \$ b / y r ) ~}$ & $40.1^{+}$ & 44.6 \\
Number of beneficiaries $(\mathbf{m})$ & 1.4 & 2.5 \\
\hline Workers per \$m of retirement income & 1.36 & 0.16 \\
Cost per \$ of retirement income (\$) & 0.90 & 0.04
\end{tabular}

funds.html and

https://www.ibisworld.com.au/industry-trends/market-research-reports/financial-insurance-services/superannuation-fundsmanagement-services.html

and PC. (2019). Superannuation: Assessing Efficiency and Competitiveness. Productivity Commission.

https://www.pc.gov.au/inquiries/completed/superannuation/assessment/report/superannuation-assessment.pdf

${ }^{6}$ ADF. (2019). Annual report. Australian Defence Force. https://www.defence.gov.au/AnnualReports/17-

18/Downloads/DAR_2017-18_Complete.pdf

${ }^{7}$ McCubbing, G. et al. (2019). Do Australians spend twice as much on superannuation fees as they do on electricity?

AAP Fact Check. https://factcheck.aap.com.au/claims/do-australians-spend-twice-as-much-on-super-fees-as-they-do-onelectricity

${ }^{8}$ APRA. (2019). Superannuation statistics. December quarter 2019. Australian Prudential Regulation Authority.

https://www.apra.gov.au/quarterly-superannuation-statistics

${ }^{9}$ DHS. (2018). Annual report 2017-18. Department of Human Services.

https://www.humanservices.gov.au/sites/default/files/2018/10/8802-1810-annual-report-web-2017-2018.pdf 


\section{Macroeconomic efficiency assessment}

Does the retirement income system stimulate economic activity, demand, and investment, or depress it? While many argue that the additional savings generated by superannuation allow for greater investment and therefore economic growth, this logic stems from a flawed understanding of macroeconomics. The confusion arises because macroeconomic theory labels spending on goods of the 'investment type', like new buildings, vehicles, or infrastructure, as 'saving'. The types of asset purchases and monetary balances that arise from the superannuation system are not investments as understood by macroeconomic theory. These savings activities merely reduce total spending in the real economy rather than boost spending on 'investment type' goods.

Non-spending of incomes on goods and services is well known to be the heart of the global stagnation of recent decades, as well as the primary mechanism by which recessions and depressions occur. The superannuation system was implemented to reduce demand in the economy during an inflationary period by reducing the spending power of workers. ${ }^{10}$

Presently, $\$ 117$ billion per year is transferred to super, with only $\$ 80$ billion in pensionstyle benefits (including lumpsum withdrawals) paid from the system, meaning the system reduces potential spending in the real economy on goods and services by $\$ 38$ billion per year. Compared to Australia's $\$ 1,970$ billion GDP, ${ }^{11}$ that is $1.9 \%$ of GDP each year being removed from cash accounts that could purchase goods and services and into asset markets (or about $\$ 3,800$ per household per year on average). Figure 3 shows the leakage of circulating funds in the real economy to asset markets something that has happened year in, year out. ${ }^{12}$

\section{Financial economy}

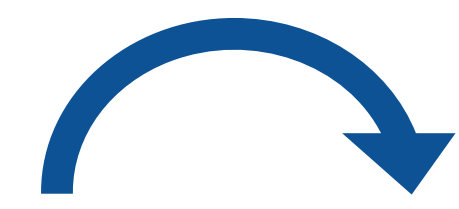

Assets

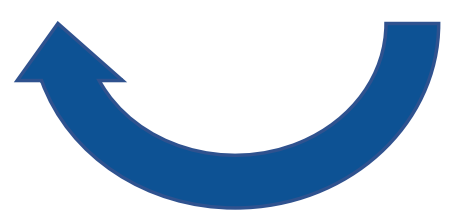

\section{Real economy}

\section{$(\$ 1,970$ b per year value add $)$}

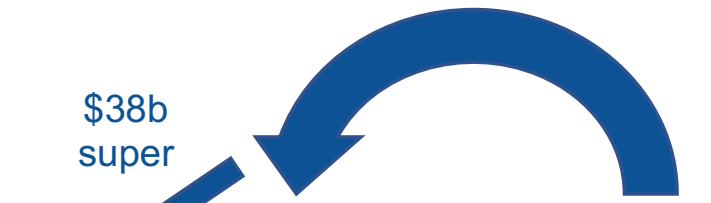

Goods and services

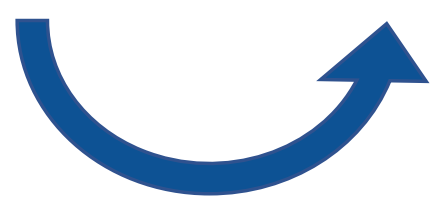

Figure 3: Leakage from the real economy to asset markets from superannuation

For perspective, the net reduction in potential spending on goods each year is roughly as big as the $\$ 40$ billion stimulus package implemented in 2009 by the Rudd government to combat the financial crisis and lift economic activity. Instead, the

\footnotetext{
${ }^{10}$ ABC Factcheck. (2016). Was superannuation designed to get people off the age pension. ABC News. https://www.abc.net.au/news/2015-11-18/fact-check-was-super-designed-to-get-people-off-the-pension/6923582

${ }^{11}$ ABS. (2019). 5206.0 Australian National Accounts. Australian Bureau of Statistics.

https://www.abs.gov.au/ausstats/abs@.nsf/mf/5206.0

12 Since 2004 there has been over $\$ 33$ billion per year of net asset purchases, ignoring earnings within the system, according to APRA statistics (see footnote 7).
} 
superannuation system does the reverse of that - creating a massive economic dampener, year in, year out.

In macroeconomic terms, the age pension is likely to be stimulatory because it transfers from high-income taxpayers with a low marginal propensity to consume, to low income pensioners with a higher marginal propensity to consume. This boosts total spending, demand, and overall economic activity and investment in the real economy.

In terms of labour force participation, the age pension is a clear winner too. With a qualifying age of 66 , compared to a reservation age of 56 for superannuation, it does not provide work disincentives for people in their late 50s. However, this is not to say that the perfect retirement income system encourages as much formal work by the elderly as possible. The question of what age society as a whole deems suitable for being supported simply because of age is a moral one. Indeed, one could argue that the appropriate qualifying age for a pension is zero - after all, if the age pension is deemed to be the adequate income needed for a decent life, there is nothing special about any particular birthday after the first one.

\section{Fairness assessment}

There are many elements to fairness, and we base our assessment around the key areas identified by the OECD - 1) coverage, poverty relief, and adequacy, 2) consumption smoothing, and 3 ) generational equity and redistribution. Table 2 summarises these main points.

\section{Coverage, poverty relief, and adequacy}

The age pension system is available to all residents over the qualifying age, provided they do not have sufficient alternative non-work income sources (i.e., they meet the income and assets tests). This ensures that coverage is complete amongst residents of a certain age and lack of resources - exactly complying with the one retirement income policy. In contrast, superannuation only covers people who have previously engaged in the formal workforce, primarily as employees and not business owners and the selfemployed. By its nature it provides retirement incomes to those who would have provided for their own retirement anyway, only with generous tax break along the way.

The same problem befalls superannuation when it comes to poverty relief. Since superannuation relies on previous earnings, the ability for superannuation to help avoid poverty is inversely proportional to the likelihood of being in poverty in old age. The amount available in superannuation is more than proportional to the product of the number of years of employment and the average wage. Those in the most need of poverty relief in old age, who may not have been able to sustain long work lives, cannot rely upon the superannuation system. The age pension, on the other hand, ensures poverty relief by being universal, subject to age limits, and phasing out as non-work income increases.

Table 2: Comparison of the fairness of retirement income systems

Superannuation

\begin{tabular}{l|cc}
\hline Coverage & No & Yes \\
Poverty relief & No & Yes \\
Benefit adequacy & No & Yes
\end{tabular}


For these same reasons, superannuation is unable to ensure the adequacy of retirement incomes except for those most able to have adequate incomes without superannuation. The age pension is able to set a level that meets a target replacement rate for a typical worker, yet superannuation cannot allow for such policy targets. Indeed, superannuation by its nature contains market risks. Even if an individual appears to have adequate funds prior to retirement, global asset price variation may radically reduce their available benefits. The super system as a whole lost $21 \%$ of its value between September 2007 and March 2009, showing just how real this risk is. ${ }^{13}$

\section{Consumption smoothing}

A fairness principle of retirement income systems is that the system allocates from individuals with high resource access (high wealth and income) to those with less. This also means that through an individual's lifetime, they will contribute to the retirement system when they are wealthier than when they receive income from it - the system smooths the lifetime consumption of an individual.

This objective has been repeated by Treasury in their recent discussion paper.

Ideally, the retirement income system should support individuals to save enough to allow consumption smoothing over their lifetime without deferring too much consumption to their retirement at the expense of living standards during working life. ${ }^{14}$

The superannuation system achieves consumption smoothing for the top $60 \%$ of earners but does the opposite for the bottom $40 \%$ of income earners. ${ }^{15}$ This is because many low-income households earn less than the age pension prior to retirement. The age pension is a pay rise for them, and yet the superannuation system forces them to have $9.5 \%$ less income when they are poorer than age pensioners.

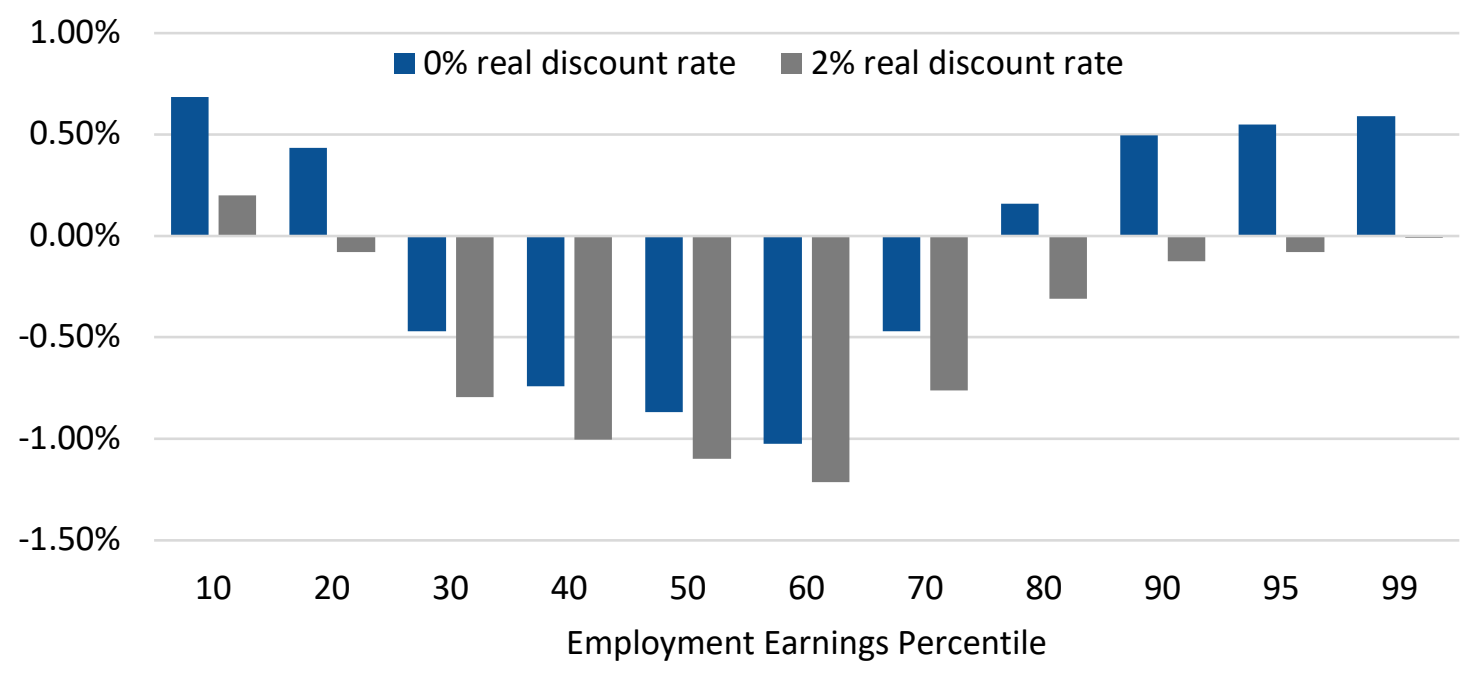

Figure 4: Change in lifetime income (CPI-deflated) from additional $2.5 \%$ compulsory super rate

Furthermore, compulsory superannuation decreases lifetime incomes for $90 \%$ of households (assuming a $2 \%$ real discount rate). Grattan Institute analysis shows the

\footnotetext{
${ }^{13}$ See footnote 7.

${ }^{14}$ Treasury. (2019). Retirement Income Review — Consultation Paper. November 2019. https://treasury.gov.au/sites/default/files/2019-11/c2019-36292-v2.pdf

${ }^{15}$ Coates, B. and Emslie, O. (2019). More compulsory super hurts Middle Australia - however you look at it. Grattan Institute Blog. 10 July 2019.https://blog.grattan.edu.au/2019/07/more-compulsory-super-hurts-middle-australia-howeveryou-look-at-it/
} 
lifetime income effects of an additional 2.5\% compulsory super (presented in Figure 4), with all earner above the $20^{\text {th }}$ percentile seeing a reduction in real lifetime incomes. ${ }^{16}$ This arises from lower current incomes from wages, and decreasing the age pension received due to the higher assets in retirement. In contrast, the age pension, when coupled with a welfare system that ensures adequate pre-retirement incomes for all, will smooth lifetime consumption for all residents.

In general, consumption smoothing policies are not necessary. If consumption smoothing is beneficial, a broad array of asset markets can allow this voluntarily, just as private insurance markets allow for smoothing expense risks.

\section{Generational equity and redistribution}

Does the retirement income system allow each generation to be provided for equally? And does the system ensure that redistribution occurs from the richer to the poorer, rather than the poor to the rich?

The answer to these questions for the age pension is yes. Each generation can be provided a level of material comfort deemed adequate. As society becomes ever richer, this task becomes easier, despite slow changes to demography that evolve far slower than overall output and productivity. Because the age pension system is funded within the overall progressive taxation framework, it redistributes from the wealthier to the poorer.

The superannuation system, however, achieves the opposite redistribution. Tax breaks on superannuation are around $\$ 45$ billion per year, mostly going to the wealthiest $10 \% .{ }^{17}$ These tax advantages entrench into retirement the inequalities that arise in the labour market, and often on to the next generation through tax-free inheritances.

Additionally, while man supported of superannuation argue that the system broadens ownership of assets in society, spreading capital incomes more widely, the opposite is more likely the case..$^{18}$ Superannuation entrenches inequality of asset ownership in society because the tax-advantages offered to purchase additional assets through super are more favourable to already-wealthy high-income earners.

\section{Myths that sustain the system}

One reason that the simple analysis above is rarely undertaken is because of pervasive myths within the economic discipline, often repeated by those with vested interests in sustaining a system that allows them to cream off $\$ 36$ billion in fees each year. ${ }^{19}$

But reality sometimes sneaks through. One myth is that there will be insufficient funds available for public age pension systems. But as Federal Reserve Bank Chairman Alan Greenspan noted in his 2005 testimony to the House of Representatives Committee on the Budget, public welfare systems can never be insolvent as there is

\footnotetext{
${ }^{16}$ Daley, J et. al. (2015). Super Tax Targeting. Grattan Institute Report No. 2015-11. https://grattan.edu.au/report/supertax-targeting/

${ }^{17}$ Australian Treasury. (2019). Tax Expenditure Statement. Budget 2018-19. https://treasury.gov.au/sites/default/files/2019-03/2017-TES.pdf

${ }^{18}$ Although the share of households that own financial assets may increase, the concentration of ownership will still be increased, i.e. the number of people with non-zero asset ownership $\neq$ lack of concentration. Say 99 out of 100 people own $1 \%$ of assets equally (the other person owning $99 \%$ ), or 50 people own $100 \%$ of assets equally (the remaining 50 owning zero), the latter is less concentrated.

${ }^{19}$ Such as the Organisation for Economic Cooperation and Developments (OECD), the World Bank, the International Monetary Fund (IMF), the Australian Treasury and various think-tanks, along with vested interest in the superannuation system, including unions.
} 
always power to create more money. ${ }^{20}$ Hence, retirement incomes systems are about allocation of real resource to retirees, not money in accounts. There is no such thing as "pre-funding" a retirement income system.

This is why we have examined the economic efficiency of alternative retirement income systems in terms of real resources. We have shown that the superannuation system uses far more resources, such as labour, to allocate a similar amount of purchasing power to retirees. The cost is around 19 times higher per dollar of retiree benefit. We have also shown that macroeconomically that the superannuation system drains spending from the real economy, dampening growth and the long-term ability to support more people to a higher standard of living with a smaller workforce.

Often the capacity of a retirement income system to allocate resources is considered in terms of the value of assets in superannuation accounts (or other retirement system funds). This is then contrasted with the lack of assets that "pre-fund" public age pension systems. However, this notion is completely ill-conceived. As the Australian Treasury recently noted:

Although individuals often focus on accumulating assets for a retirement 'nest egg', generating income to support consumption in retirement is the primary purpose of the system. ${ }^{21}$

Indeed, forcing money into the financial system through superannuation inflates asset prices. When the superannuation system is mature, and the net flow of funds is the opposite direction, the price effects from net asset selling may result in income flows from superannuation that are far below forecast.

Another myth is that having a longer-lived and healthier population - also known as population ageing - makes it more difficult to fund an age pension system. As we have noted, however, all retirement income systems at their core are tools to reallocate real resources at the time they are needed to retirees. If ageing is a problem for the age pension, it is equally a problem for the superannuation system-though it is not at all an economic problem.

In fact, countries with more rapidly ageing populations typically have more new capital investment, higher rates of participation in the labour force, and faster growth, creating more real resources able to be allocated to retirees. ${ }^{22}$ If anything, ageing is an economic blessing, not something to be feared. ${ }^{23}$

Finally, there is a myth that is especially prevalent in the labour movement, which is that increases to the rate of compulsory superannuation constitute a pay rise to labour that they would not otherwise get. Never mind that Paul Keating claimed the opposite for two decades. ${ }^{24}$

But even if there is an equilibrium effect from forcing higher wages through super because of nominal rigidities, it is not clear why this wouldn't also be the case for non-

\footnotetext{
${ }^{20}$ Greenspan, A. (2014). Economic outlook and current fiscal issues. Testimony of Federal Reserve Officials. https://www.federalreserve.gov/boarddocs/testimony/2005/20050302/default.htm Specific responses about insolvency questions available at https://www.youtube.com/watch?v=DNCZHAQnfGU

${ }^{21}$ See footnote 12.

22 Murray, C.K. and L. van Onselen. (2019). Three Economic Myths about Ageing: Participation, Immigration and Infrastructure. MacroBusiness Consulting. April 2019. https://www.fresheconomicthinking.com/2019/04/three-economicmyths-about-ageing.html

${ }^{23}$ This is in contrast to statements by Australian Treasury "Australia's ageing population means there will be a declining number of workers for every retiree. (p17)" This ignores changing work patterns.

Australian Treasury. (2019). Retirement Income Review Consultation paper. November 2019. https://treasury.gov.au/sites/default/files/2019-11/c2019-36292-v2.pdf

${ }^{24}$ Van Onselen, L. (2019). Paul Keating's superannuation incoherence deepens. MacroBusiness.

https://www.macrobusiness.com.au/2019/10/paul-keatings-superannuation-incoherence-deepens/
} 
super legislated wage rises. If there is a political will to force total nominal wages up using superannuation, nominal wages could be forced up by other means. In any case, we know super comes from wages because allowing people to spend out of their super account would transform $100 \%$ of it into wages. This is the alternative when assessing whether super comes from wages or profits.

Those who share in the $\$ 36$ billion in annual fees to manage Australia's superannuation system have a strong interest in perpetuating these myths, including labour unions and the Labor party. They now lobby to take more of their members' wages to give to the financial industry, rather than allowing them to spend it as they wish.

Unfortunately, the general public has bought into these myths. Otherwise intelligent people have been convinced that taking poor people's money, to make them even poorer, and giving it to expensive investment managers, is a great solution to poverty. People have no idea that the age pension, which is often complained about for being at poverty levels, is a pay rise for the bottom third of households about to enter retirement.

\section{How to boost wages, growth, well-being, and retirement}

Australia is one of the richest countries in the world at the richest point in history with the healthiest and longest-lived populations. Yet rather than take advantage of this situation by decreasing the need for work in the formal economy, we have instead collectively chosen to reduce our economic performance by enacting a non-solution (compulsory tax-advantaged asset purchases, aka superannuation) to a non-problem (ageing and retirement incomes), while forcing low-income people to work years longer (by ratcheting up the age pension qualifying age).

\section{Scrap superannuation}

The best course of action is to scrap superannuation. Unwind the system. Employers would be made to pay super to their employee's regular bank account rather than a separate account. During a transition period of, say, ten years, people could withdraw from their existing super account to spend on anything they like up to a yearly maximum, of, say, $\$ 20,000 .{ }^{25}$ This change would massively stimulate economic activity, increasing the real output of the economy, allowing more retirees to be supported to a higher standard of living.

\section{Scrapping the superannuation system would massively improve Australia's economic performance, and hence the performance of our only retirement income system, the age pension.}

Instead of channelling incomes through asset markets, decreasing demand and soaking up a workforce the size of the military on an accounting exercise, the 28 million superannuation account holders ${ }^{26}$ spend up to an additional $\$ 20,000$ per year, depending on their tax situation. That is $\$ 530$ billion per year, or about $23 \%$ of GDP, that will be made available. Most people will not spend the maximum from their super account, but there is no doubting the stimulatory effect of this change for the real economy - something that is sorely needed as wages reach nearly a decade of stagnation.

In addition, take-home wages will effectively increase by $9.5 \%$ across the board. Rather than going into asset purchase programs in super funds, this income will either be 1) taxed, 2) spent by income earners, or 3) saved and used for asset purchases outside of

\footnotetext{
${ }^{25}$ Defined benefits schemes can have a calculated annual withdrawal amount.

${ }^{26}$ APRA statistics show 600,000 self-managed funds, plus 26.8 million members in funds with more than four members according to ASFA (see footnote 7).
} 
super. This is a truly massive welfare benefit for the bottom $80 \%$ of households who will get a higher lifetime income.

After a ten-year transition period, all remaining super balances would be treated for tax purposed like any other asset, with no limits on how these assets are traded or sold.

Minor tweaks to the superannuation system, such as reducing tax benefits and removing the ability to take lumpsum payments, does not substantially change the previous assessments, and may simply add to compliance and administration costs, making the system even less efficient. Fundamentally, super is based on a flawed premise that compulsory tax-advantaged savings for income earners is a retirement income system rather than a wealth-enhancement system for the already wealthy.

\section{Enhance the only retirement income system we have}

The effect on government budgets from this scrapping superannuation would be to reign in the $\$ 45$ billion per year of super tax breaks, plus earn the gain in GST and other tax revenue arising from economic stimulatory effects. This would allow the age pension system to be enhanced in both size (payment rates, including rent assistance ${ }^{27}$ ) and scope (reducing the age that people qualify from 67 to 60 ).

Reducing the age pension age may seem radical to some. But compared to employing 55,000 people to shuffle numbers in spreadsheets at a cost of $\$ 36$ billion per year while sapping demand in the real economy, it should appear eminently sensible. One of the biggest issues in the labour market is the difficulty of older people regaining employment. There is no reason that someone who is 60 and in poor health after a tough working life, should be treated as unworthy of income support compared to a healthy 67 -year-old. Over 140,000 people aged 50-64 get unemployment benefits. The face of unemployment in Australia is a grey and wrinkly one because we have chosen to shrink retirement as we became wealthier, rather than expand it.

Broadening the age pension to those aged 60 and up may mean that fewer people aged 60 to 67 work in the formal economy. But any effect will be less than the effect of superannuation, which can be accessed at age 56 and only for those who have participated in the formal workforce. Moreover, the labour market effects of providing income support are a non-issue, economically speaking. The top $20 \%$ of households already have a mean net worth of $\$ 3.3$ million, more than enough to live a comfortable life without the need to work at all. ${ }^{28}$ Yet, most households in this group have members who work in long and productive careers. If it makes sense to force people to work by reducing non-work incomes, then these people should be the primary target.

\section{Turn the retirement income system into a citizen income?}

The logic of extending retirement incomes to 60 -year-olds extends all the way back to birth. If a 60-year-old is worthy of income support, why not a 59-year-old? The theoretically ideal qualifying age for a retirement income is zero. If the age pension is the socially acceptable minimum income required for a comfortable life, there is no reason why the logic that argues for supporting the elderly financially should not extent to everyone. The massively successful age pension could be extended to all residents to create a universal income, making participation in the formal workforce optional, just as it is for the wealthy who have significant non-work income sources.

\footnotetext{
${ }^{27}$ Grattan Institute has forcefully prosecuted the first point. With housing rents being a large share of expenses, renting age pensioners are at a massive disadvantage. Yet the asset value of one's own home is of no consequence to receiving the age pension. Increasing the rent allowance for age pensioners would be a huge step to repairing the inequality between renters and homeowners in the age pension system.

${ }^{28}$ ABS. (2018). 6523.0 - Household Income and Wealth, Australia, 2017-18.

https://www.abs.gov.au/ausstats/abs@.nsf/mf/6523.0
} 